\title{
Temperature and isotopic relations in carbonate minerals in the Middle Jurassic sideritic rocks of central and southern Poland
}

\author{
Katarzyna JARMOŁOWICZ-SZULC ${ }^{1, *}$ and Aleksandra KOZŁOWSKA ${ }^{1}$ \\ 1 Polish Geological Institute - National Geological Institute, Rakowiecka 4, 00-975 Warszawa, Poland
}

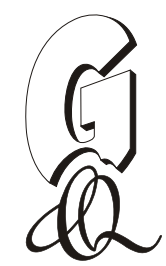

\begin{abstract}
Jarmołowicz-Szulc, K., Kozłowska, A., 2016. Temperature and isotopic relations in carbonate minerals in the Middle Jurassic sideritic rocks of central and southern Poland. Geological Quarterly, 60 (4): 881-892, doi: 10.7306/gq.1323

The present study assesses the physico-chemical character of the fluids responsible for the genesis of carbonate minerals in the Middle Jurassic sideritic rocks at the northeastern margin of the Holy Cross Mts. and in the Czestochowa region. These rocks occur at present at depths between 30 and $600 \mathrm{~m}$. Fluid inclusion and isotopic analyses have been performed in the carbonate minerals from sideritic sandstones, clayey siderites and sideritic coquinas. Siderite is the main carbonate mineral of the sideritic rocks. Calcite and ankerite are also present. The siderite is represented by two varieties, Mg-rich siderite (sideroplesite, less commonly - pistomesite) and siderite. Two generations of siderite have been distinguished - an early and a late one. The early siderite was formed at temperatures of about $20^{\circ} \mathrm{C}$ in the zone of microbiological methanogenesis from marine waters with some influence of meteoric waters $\left(\delta^{18} \mathrm{O}\right.$ from -7.84 to $-1.92 \%$ VSMOW). The late siderite crystallized at temperatures of about $62-110^{\circ} \mathrm{C}$ from pore waters enriched in ${ }^{18} \mathrm{O}\left(\delta^{18} \mathrm{O}>0 \% \mathrm{VSMOW}\right)$ as compared with the isotopic composition of the waters responsible for the early siderite generation. The conducted fluid inclusion analyses point to formation of the cements from complex fluids of brine and carbon dioxide character, with densities slightly exceeding $1 \mathrm{~g} / \mathrm{cm}^{3}$ and salinities varying from 10.5 to $16.9 \mathrm{wt} . \% \mathrm{NaCl}$ eq. and from 6.4 to $14.0 \mathrm{wt} . \% \mathrm{NaCl}$ eq. in the Holy Cross Mts. and in the Częstochowa region, respectively. The homogenization temperatures lie in the intervals of $62-110^{\circ} \mathrm{C}$ and $60-97^{\circ} \mathrm{C}$, respectively and represent elevated values compared with data from the Polish Lowlands. Apart from burial, other heat sources must have been important for the lithogenesis of the Middle Jurassic deposits.
\end{abstract}

Key words: fluid inclusions, isotopes, carbonate minerals, sideritic rocks, Middle Jurassic.

\section{INTRODUCTION}

The term "siderite" encompasses minerals of the solid solution series between siderite and magnesite, most frequently, sideroplesite and pistomesite (Bolewski, 1982). Most hitherto published papers present temperature conditions responsible for vein siderites or magnesites of hydrothermal origin (e.g., Hein, 1993; Hurai et al., 2002; Lugli et al., 2002; Schmidt Mumm and Wolfgamm, 2002; Fernández-Nieto et al., 2003; Strmić Palinkaš et al., 2009; Palinkaš et al., 2016). Few papers provide data on fluid inclusions in siderites from sedimentary rocks (Rezaee and Schulz-Rojahn, 1998).

A basis for fluid inclusion studies is an assumption that during the crystallisation of pore-filling minerals in sedimentary rocks, small amounts of basin fluids are trapped (Roedder, 1984). Generally, the fluid inclusions are relict portions of the solutions that no longer exist. Therefore, thermal and isotopic studies may serve to reconstruct the primary conditions of mineral formation and of the composition and density of palaeofluids (Jarmołowicz-Szulc, 1999). Information on the primary

\footnotetext{
${ }^{*}$ Corresponding author, e-mail:

katarzyna.jarmolowicz-szulc@pgi.gov.pl
}

Received: June 3, 2016; accepted: October 12, 2016; first published online: November 2, 2016 volume and composition should remain preserved. This is very difficult to constrain in the sedimentary rocks, which may be deeply buried and subsequently uplifted. Fluid inclusion bearers show variable resistance towards external conditions, which is why temperature results obtained for them may vary in significance (Jarmołowicz-Szulc, 2015).

In diagenetic studies, thermometric interpretation has to take into account a number of factors (Goldstein, 2001). First, the character of fluid inclusions (primary or secondary) needs to be considered. Next, the measured values may reflect a wide range of salinity, because the crystals have grown from mixed fluids. Then, deep burial of deposits may cause stretching and leakage of inclusions, so the temperature values obtained may not correspond to primary conditions of mineral formation (Goldstein, 1986).

The present research demonstrates the significance of fluid inclusions in relation to carbonate cements, mainly siderite, locally ankerite and calcite. The inclusion and stable isotope data served as a geological thermometer. Additionally, carbon and oxygen isotope ratios in carbonate minerals have been used for calculation of the isotopic composition of the fluid from which these minerals have crystallized. Thus, fluid inclusion analysis accompanied by isotopic studies of the carbonate minerals in the sideritic rocks from two areas of Poland - the northeastern margin of the Holy Cross Mts. and the Częstochowa region (Fig. 1) contributed to better understanding of the origin of these siderite deposits. 


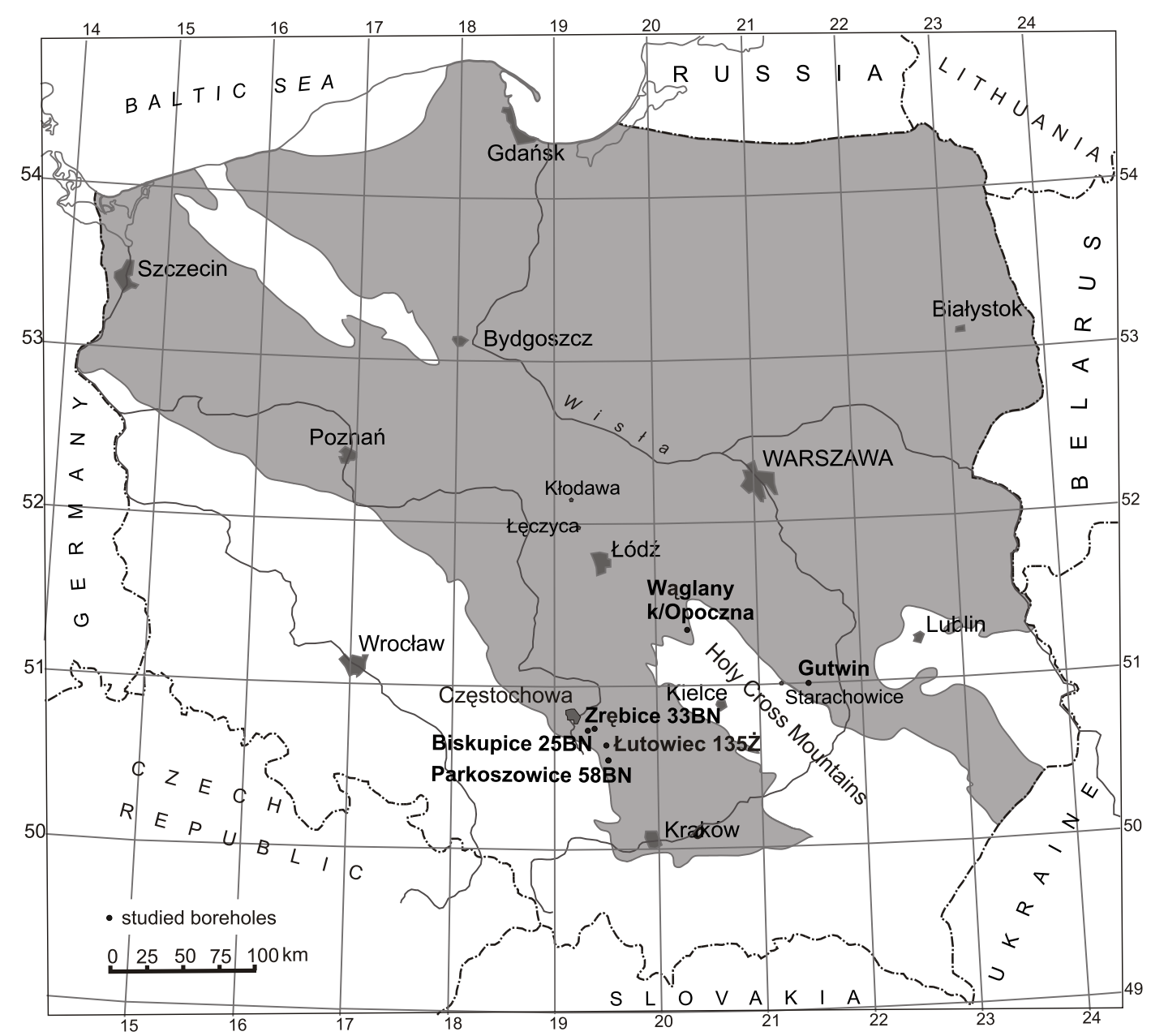

Fig. 1. Map of locality of boreholes analysed in the present study

Grey colour shows extent of the Middle Jurassic in Poland (after Lott et al., 2010, modified)

\section{GEOLOGICAL SETTING AND STUDY AREA}

The study area (Fig. 1) represents a southern part of the Polish Basin that during the Jurassic was the eastern arm of the Central European Basin System (Pieńkowski et al., 2008). The thickness of the Middle Jurassic strata at the northeastern margin of the Holy Cross Mts. varies from $180 \mathrm{~m}$ (south-east) to about $800 \mathrm{~m}$ (north) (Daniec, 1970). The deposits are represented by sandstones and mudstones with interbeds of claystones and sideritic iron ores, mainly of Aalenian, Bajocian and Bathonian age (Kozłowska and Maliszewska, 2015). The thickness of the Middle Jurassic strata in the Czestochowa region changes from $85 \mathrm{~m}$ (south) to about $184 \mathrm{~m}$ (north) (Kopik, 1998). The deposits are composed of Bajocian and Bathonian sandy claystones and mudstones, which locally contain dark claystones with siderite (known as ore-bearing clays; Kopik 1998). The difference in the thickness of the Middle Jurassic deposits between the two areas under discussion results from their palaeogeographic position within the epicontinental basin. It is presumed that the northeastern margin of the Holy Cross Mts. occupied the central part of the basin, whereas the Częstochowa region a marginal part (Feldman-Olszewska, 1998).
The sideritic rocks were collected from two boreholes at the northeastern margin of the Holy Cross Mts. (Gutwin and Waglany k/Opoczna) and from four boreholes in the Częstochowa region (Biskupice 25BN, Łutowiec 135Ż, Parkoszowice 58BN and Zrębice 33BN) (Fig. 1 and Table 1). The deposits occur at depths varying from 30 to $600 \mathrm{~m}$. The samples studied in the Częstochowa area are from moderate depths between $\sim 100 \mathrm{~m}$ to at maximum $\sim 380 \mathrm{~m}$ (Parkoszowice 58BN - depth from 101.3 to 104.2 m; Biskupice 25BN - depth 134.7 m; Łutowiec $135 Z$ - depth 178.9 m; Zrębice 33BN - depth $372.7 \mathrm{~m}$ ), while the sandstones studied at the northeastern margin of the Holy Cross Mts. lie much deeper, up to about $650 \mathrm{~m}$ (Gutwin - depth $201.6 \mathrm{~m}$; Waglany k/Opoczna - depth from 267.7 to $643.8 \mathrm{~m}$ ).

Lithological sections of the Gutwin and Łutowiec $135 Z$ boreholes by Kozłowska and Maliszewska (2015) are shown in Figure 2. A simplified section of the Zrębice 33BN borehole may be found in Leonowicz (2015). According to Feldman-Olszewska (pers. comm., 2013), the rocks represent various Middle Jurassic sedimentary environments, such as the offshore, transition zone, shoreface, deltaic and estuarian regimes. Siderite layers and concretions, and sideritic sandstones, are observed mainly in the Aalenian, Bajocian and Bathonian rocks, at the northeastern margin of the Holy Cross Mts. and in the Bajocian and 


\section{Sideritic samples studied}

\begin{tabular}{|c|c|c|c|c|c|c|c|c|}
\hline Area & Borehole & $\begin{array}{c}\text { Depth } \\
{[\mathrm{m}]}\end{array}$ & Age & $\begin{array}{c}\text { Type } \\
\text { of rocks }\end{array}$ & $\begin{array}{c}\text { Vol.\% } \\
\text { of siderite }\end{array}$ & $\begin{array}{c}\text { Type } \\
\text { of siderite }\end{array}$ & $\begin{array}{c}\text { Vol.\% of other } \\
\text { carbonate minerals }\end{array}$ & Method \\
\hline \multirow{7}{*}{$\begin{array}{l}\text { Northeastern } \\
\text { margin of the } \\
\text { Holy Cross Mts. }\end{array}$} & Gutwin & 201.6 & $B j 2$ & sst & 28.0 & $\mathrm{Sdp} \mathrm{Pt}$ & $12.7 \mathrm{Ak}$ & PL EDS FI \\
\hline & \multirow{6}{*}{$\begin{array}{l}\text { Waglany } \\
\text { k/Opoczna }\end{array}$} & 267.7 & $\mathrm{Bt3}$ & scq & 16.0 & Sdp & $36.3 \mathrm{Ak}$ & PL EDS FI \\
\hline & & 395.2 & Bt1-2 & cls & 57.7 & Sdp & 0.0 & PL EDS FI IS \\
\hline & & 406.0 & Bt1-2 & cls & 59.7 & Sdp Pt & 0.0 & PL FI \\
\hline & & 597.2 & Aa1 & cls & 67.4 & Sd Sdp Pt & 0.0 & PL EDS FI \\
\hline & & 600.2 & Aa1 & sst & 32.7 & Sdp Pt & 0.0 & PL EDS FI IS \\
\hline & & 643.8 & Aa1 & sst & 43.7 & Sdp & 0.0 & PL EDS FI IS \\
\hline \multirow{6}{*}{$\begin{array}{l}\text { Częstochowa } \\
\text { region }\end{array}$} & Biskupice 25BN & 134.7 & Bt1 & sst & 40.0 & Sdp Pt & $18.0 \mathrm{Ca}$ & PL CL EDS FI IS \\
\hline & Łutowiec $135 Z ̇$ & 178.9 & $\mathrm{Bj} 1$ & cls & 50.3 & Sdp & & PL EDS FI IS \\
\hline & \multirow{3}{*}{$\begin{array}{c}\text { Parkoszowice } \\
58 \mathrm{BN}\end{array}$} & 101.2 & $\mathrm{Bj} 2$ & cls & 65.0 & Sdp & $5.0 \mathrm{Ca}$ & PL FI \\
\hline & & 102.3 & $\mathrm{Bj} 2$ & cls & 72.0 & Sdp & 0.0 & PL CL EDS FI IS \\
\hline & & 104.1 & $\mathrm{Bj} 2$ & cls & 76.0 & Sdp & $3.0 \mathrm{Ca}$ & PL CL EDS FI \\
\hline & Zrębice 33BN & 372.7 & $\mathrm{Bj} 2$ & sst & 30.0 & Sd Sdp & 0.0 & PL CL EDS FI IS \\
\hline
\end{tabular}

$\mathrm{Ak}$ - ankerite, $\mathrm{Ca}$ - calcite, Sd - siderite, Sdp - sideroplesite, Pt - pistomesite; cls - clayey siderite, sst - sideritic sandstone, scq - sideritic coquina, mic - micrite, msp - microsparite, sp - sparite, rb - rhombohedron, Sph - spherulite; Aa1 - Lower Aalenian, Aa2 - Upper Aalenian, Bj1 - Lower Bajocian, Bj2 - Upper Bajocian, Bt1 - Lower Bathonian, Bt2 - Middle Bathonian, Bt3 - Upper Bathonian; PL - polarizing microscope, CL - cathodoluminescence, EDS - microprobe analysis, FI - fluid inclusions, IS - isotope analysis

Bathonian rocks of the Częstochowa region (Kozłowska and Maliszewska, 2015).

There are a number of recent papers on the stratigraphy, sedimentology, geochemistry and palaeoenvironments of the Middle Jurassic strata of the Częstochowa region (e.g., Majewski, 2000; Marynowski et al., 2007; Szczepanik et al., 2007; Wierzbowski and Joachimski, 2007; Zatoń et al., 2009; Gedl and Ziaja, 2012; Witkowska, 2012; Leonowicz, 2012, 2013, 2015). The Middle Jurassic deposits at the northeastern margin of the Holy Cross Mts. were studied by Kozłowska and Maliszewska (2015). Their research was focused on the mineralogy and petrography of the sideritic rocks. The mineralogy of the Middle Jurassic sideritic concretions in the Silesian-Cracow Monocline was studied by Krzykawski (2012) and Witkowska (2015). Siderites in the Carboniferous sandstones from the Lublin Graben close to the study areas were described by Kozłowska (1997, 2001, 2004).

\section{METHODOLOGY}

\section{GENERAL ANALYTICAL PROCEDURES}

The analytical procedures comprised sampling and preparation, microscopy of the minerals and inclusions, geochemical analyses, and auxiliary studies.

Based on observations of 276 thin sections using a Nikon Eclipse LV $100 \mathrm{Pol}$ polarizing microscope, 13 samples were selected for further study (Table 1). Thin-sections were stained with Evamy's solution to identify the carbonate minerals. Four samples were subjected to cathodoluminescence analysis using the so-called "cold cathode", CITL MK5 type from Cambridge Image
Technology Ltd. (voltage 16kV, current $600 \mu \mathrm{A}$ ). The chemical composition of the carbonate minerals was determined on 12 samples (Appendix $1^{*}$ ). Microchemical studies were performed using an electron scanning microscope LEO 1430, combined with EDS ISIS. Uncovered carbon-coated thin-sections were analysed. Back-scattered electron images (BSE) were also made. The studies were conducted in the Polish Geological Institute - National Research Institute in Warsaw.

\section{PREPARATION AND ANALYTICAL TECHNIQUES FOR FLUID INCLUSION STUDIES}

13 samples for fluid inclusion studies were prepared using standard preparation techniques (Shephard et al., 1985; Jarmołowicz-Szulc, 2001). Double-sided-polished thin sections, $0.1-0.2 \mathrm{~mm}$ thick, were obtained for low temperature mounting. Microscopic observations were conducted using a polarizing microscope in transmitted and reflected (UV) light. The analytical steps corresponded to a microscopic analysis of fluid inclusions (Leitz Orthoplan), fluorescence studies and microphotography (Nikon microscope and UV device) as well as microthermometric analyses. The latter included heating and freezing using a Fluid Inc. System, mounted on a Leitz Orthoplan microscope and the Linkam equipment with digital microphotography. The Fluid Inc. System and the Linkam stage were calibrated against melting temperatures of the pure chemicals and phase transitions in synthetic fluid inclusions (SYNFLINC standards; Reynolds 1993). The uncertainty limits are $0.2^{\circ} \mathrm{C}$ below $-100^{\circ} \mathrm{C}, 0.1^{\circ} \mathrm{C}$ between -100 and $+100^{\circ} \mathrm{C}$, and $0.2^{\circ} \mathrm{C}$ above $100^{\circ} \mathrm{C}$. Fluid inclusions in the cements were studied by freezing in order to avoid volume changes of the inclusions. The measurements embraced homogenization temperatures and determinations of eutectic and ice melting temperatures of the brine inclusions (Appendix 2). 
A Northeastern margin of the Holy Cross Mountains

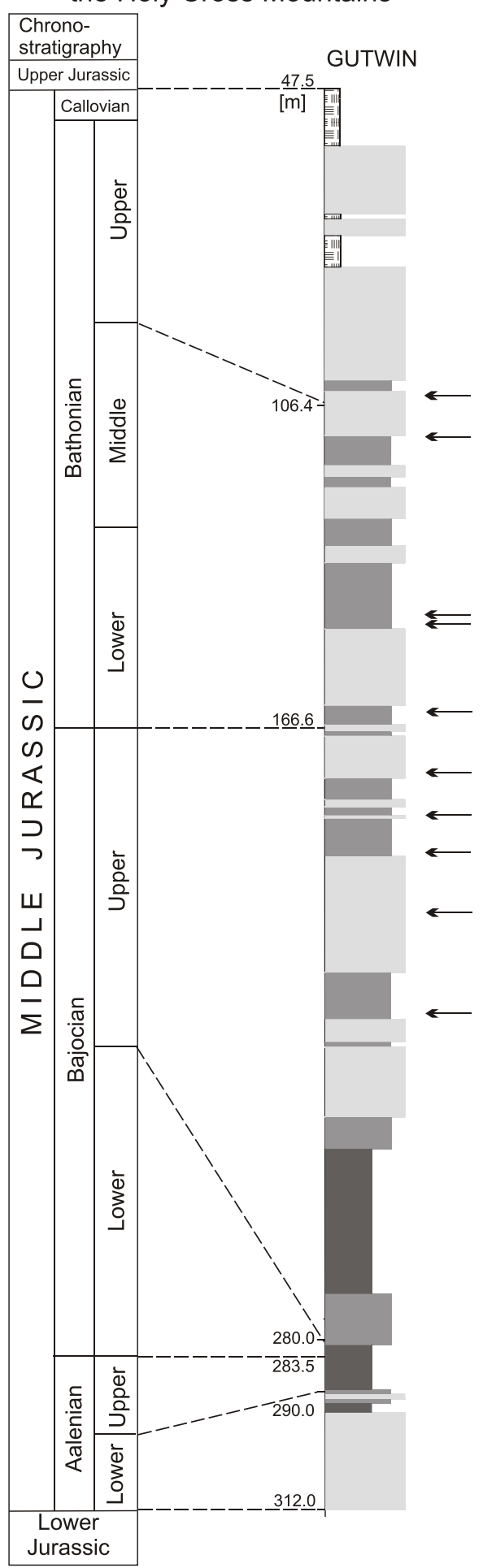

\section{B Częstochowa region}

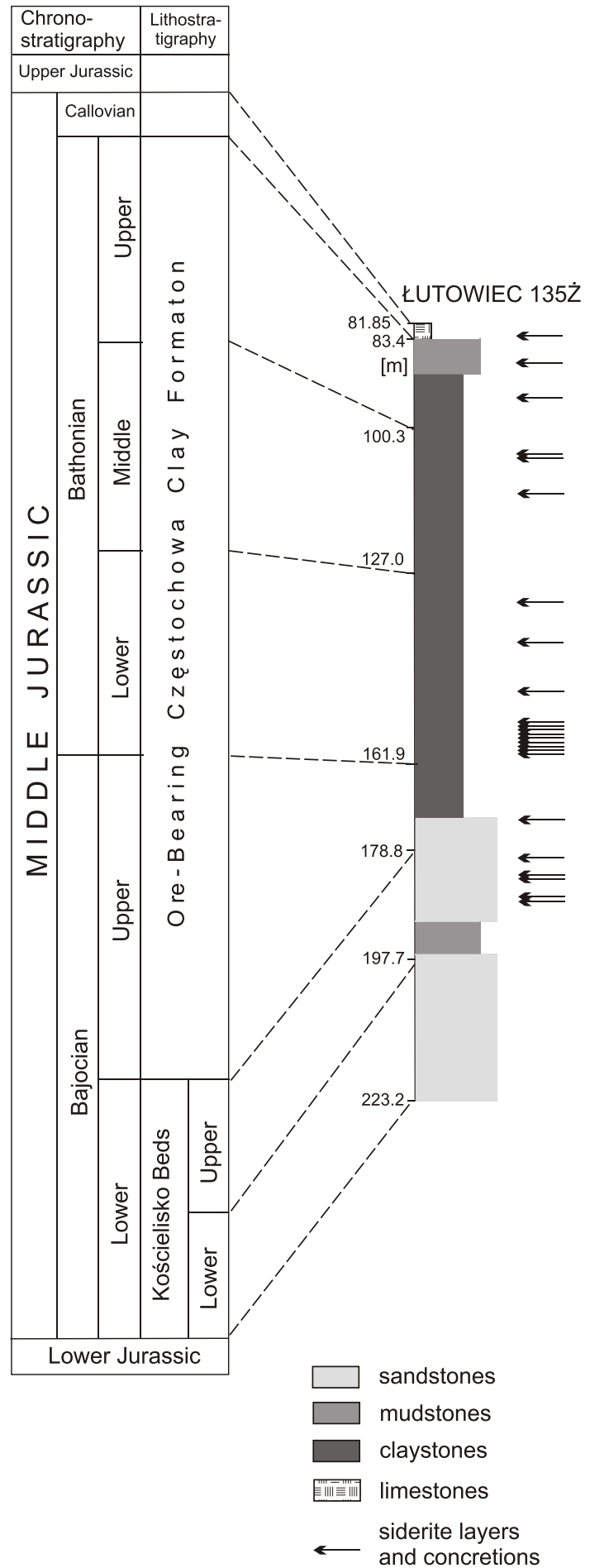

Fig. 2. Lithological sections of the Middle Jurassic deposits (after Kozłowska and Maliszewska, 2015)

Temperature of homogenization was approximated as the temperature of trapping due to small pressure correction in fluid inclusions which homogenize into liquid phase (Roedder, 1984). Isochores were calculated with the Flincor program (Brown, 1989) and FLUIDS package (Bakker, 2003). Different varieties of the FLUIDS package, mainly AqSo1e (Bakker and Brown, 2003), were applied.
ISOTOPIC STUDIES

Analyses of the isotopic composition of oxygen and carbon in seven siderite and one calcite samples were conducted in the Isotope Laboratory of the Maria Curie-Skłodowska University at Lublin (Table 2). The method was described by Durakiewicz and Hałas (1994) and Durakiewicz (1996). Gaseous carbon dioxide 
Carbon and oxygen isotope data of the carbonates in the sideritic rocks

\begin{tabular}{|c|c|c|c|c|c|c|c|c|c|}
\hline \multirow{2}{*}{ Borehole } & \multirow{2}{*}{ Age } & \multirow{2}{*}{$\begin{array}{l}\text { Depth } \\
\text { [m] }\end{array}$} & \multirow{2}{*}{ Type of carbonate } & \multicolumn{2}{|c|}{ Content [\%] } & \multirow{2}{*}{$\begin{array}{c}\delta^{13} \mathrm{C} \text { VPDB } \\
{[\% 0]}\end{array}$} & \multirow{2}{*}{$\begin{array}{c}\delta^{18} \mathrm{O} \text { VPDB } \\
{[\% 0]}\end{array}$} & \multirow{2}{*}{$\begin{array}{l}\delta^{18} \mathrm{O} \\
\text { VSMOW } \\
{[\% 0]}\end{array}$} & \multirow{2}{*}{$\begin{array}{c}{ }_{[\%]}^{*} \delta^{18} \mathrm{O} \\
{[\% \mathrm{~W}} \\
\mathrm{H}_{2} \mathrm{O}\end{array}$} \\
\hline & & & & $\mathrm{S} 1$ & $\mathrm{~S} 2$ & & & & \\
\hline \multicolumn{10}{|c|}{ Northeastern margin of the Holy Cross Mts. } \\
\hline \multirow{4}{*}{ Waglany k/Opoczna } & Bt1-2 & 395.2 & Sdp msp cement, sp ooid & 70 & 30 & -17.68 & -3.86 & 26.88 & -7.01 \\
\hline & \multirow{2}{*}{ Aa1 } & \multirow{2}{*}{600.2} & Sdp msp cement & 100 & 0 & -8.63 & -7.84 & 22.78 & -11.11 \\
\hline & & & Pt sp rb cement & 0 & 100 & -9.58 & -10.45 & 20.08 & - \\
\hline & Aa1 & 643.8 & Sdp sp rb cement & 0 & 100 & -10.83 & -8.82 & 21.77 & - \\
\hline \multicolumn{10}{|c|}{ Częstochowa region } \\
\hline Biskupice 25BN & Bt1 & 134.7 & $\begin{array}{c}\text { Sdp mic cement, Sdp Pt } \\
\text { sp rb cement } \\
\text { Ca cement }\end{array}$ & 60 & 40 & $\begin{array}{l}-7.48 \\
-2.01\end{array}$ & $\begin{array}{l}-2.01 \\
-5.38\end{array}$ & $\begin{array}{l}28.80 \\
25.32\end{array}$ & $\begin{array}{c}-5.10 \\
-\end{array}$ \\
\hline Łutowiec $135 \dot{Z}$ & Bj1 & 178.9 & Sdp msp, sp rb cement & 85 & 15 & -22.85 & -1.92 & 28.89 & -5.01 \\
\hline Parkoszowice 58BN & $\mathrm{Bj} 2$ & 102.3 & Sdp sp cement & 80 & 20 & -8.87 & -3.81 & 26.94 & -6.95 \\
\hline Zrębice 33BN & $\mathrm{Bj} 2$ & 372.7 & $\begin{array}{l}\text { Sd Sdp Sph msp, sp rb } \\
\text { cement }\end{array}$ & 15 & 85 & -11.52 & -3.45 & 27.31 & -6.58 \\
\hline
\end{tabular}

${ }^{*} \delta^{18} \mathrm{O}$ VSMOW water of sideroplesite which crystallized at a temperature of $20^{\circ} \mathrm{C}$; S1 - early generation of siderite; S2 - late generation of siderite; for explanations see Table 1

was released from carbonates during reaction with phosphoric acid (Mc Crea, 1950; Al-Aasm et al., 1990). Isotope measurements of carbon and oxygen were conducted in the modified mass spectrometer MI 1305 with a measurement precision of $\pm 0.08 \%$ (one sigma). Measurements were conducted with reference to international standards (Durakiewicz,1996). The values of $\delta^{13} \mathrm{C}$ were expressed at the scale of the VPDB, while $\delta^{18} \mathrm{O}$ results were obtained in the VPDB and VSMOW scales.

\section{CHARACTERISTICS \\ OF THE SIDERITIC ROCKS}

The material studied comes mainly from clayey siderites and sideritic sandstones (Fig. 3), locally from sideritic coquinas. Siderite is the main component of the sideritic rocks. This mineral represents Mg-rich siderite (sideroplesite, less frequently pistomesite), and locally siderite.

The clayey siderites contain micritic, microsparic and spar siderite and clay minerals. Sideroplesite is the main siderite mineral (micrite, microspar, spar), while pistomesite (microspar, spar) and the siderite (micrite, spar) appear locally. The sideroplesites show the following chemical composition (in mol.\%): 77.4-85.8 - $\mathrm{FeCO}_{3}, 6.5-9.3-\mathrm{MgCO}_{3}, 6.6-13.3-$ $\mathrm{CaCO}_{3}$ and $0.0-1.5-\mathrm{MnCO}_{3}$ (Appendix 1). Clay minerals are represented by kaolinite, berthierine and illite (Kozłowska and Maliszewska, 2015). Calcite and ankerite are the other carbonate minerals present in the rock. Quartz grains of silt- and sand-size occur in varying amounts. Feldspar grains, mica flakes, zircon, pyrite, hematite and the organic matter are accessory components. Calcitic, locally pyritized, faunal fragments are common. Clay and carbonate ooids were observed in a few samples. The carbonate ooids are composed mainly of sparry sideroplesite or pistomesite, rarely of calcite and ankerite. Locally, clayey siderites are cut by calcite, ankerite and/or pyrite veins.

The sideritic sandstones are represented by fine- to medium-grained quartz arenites. Quartz is the main detrital material and feldspars, micas and zircon are subordinate. Shell fragments and ooids are observed in variable amounts. Fragments of bivalves, echinoderms, gastropods and foraminifers are composed of carbonate minerals (commonly calcite, occasionally of ankerite and siderite) and clay minerals (kaolinite and berthierine). Ooids consist mainly of berthierine, sparitic sideroplesite or calcite and locally of kaolinite and pyrite. The main cements in the sandstones are carbonates, as sideroplesite (micritic, microsparitic, sparitic) and pistomesite (sparitic), siderite (micritic, sparitic), ankerite and calcite. The most common sideroplesites show the following chemical composition (in mol.\%): 75.3-86.3$\mathrm{FeCO}_{3}, 5.9-21.4-\mathrm{MgCO}_{3}, 1.9-16.2-\mathrm{CaCO}_{3}$ and 0.0-4.2 $\mathrm{MnCO}_{3}$ (Table 2). Clay minerals such as berthierine, kaolinite, illite and locally chlorite also occur (Kozłowska and Maliszewska, 2015). Locally, the sideritic sandstones are cut by calcite, ankerite, sideroplesite and/or pistomesite veins.

The sideritic coquina (bioclasts $20 \%$ of rock volume) from the Waglany k/Opoczna borehole is composed mainly of ooids and bioclast fragments, such as echinoderms, bivalves, brachiopods, gastropods and bryozoans. The berthierine ooids have been replaced to a variable degree by ankerite and sideroplesite. The cement is composed of microsparry and sparry sideroplesite and ankerite (Appendix 1).

\section{CHARACTERISTICS OF THE CARBONATE MINERALS STUDIED}

Siderite is the main carbonate mineral studied in the sideritic rocks, while calcite and ankerite are less frequent. The Mg-rich siderite represents sideroplesite and pistomesite of microspar and spar crystal size (Fig. 3), very often in the form of rhombohedra. Two siderite generations - early and late ones - may be distinguished based on the microscopic observations. The early generation is represented by micritic and microsparitic sideroplesite, locally by siderite, whereas the late one has sparitic (partly rhombohedric) sideroplesite (Fig. 4A) and rare pistomesite. The rhombohedra are more frequent in the sideritic rocks at the northeastern margin of the Holy Cross Mts. than in the Częstochowa region (Appendix 1). Rhombohedric crystals of sideroplesite and pistomesite often display zonal structure, related to the varying contents of iron and magnesium, as well 

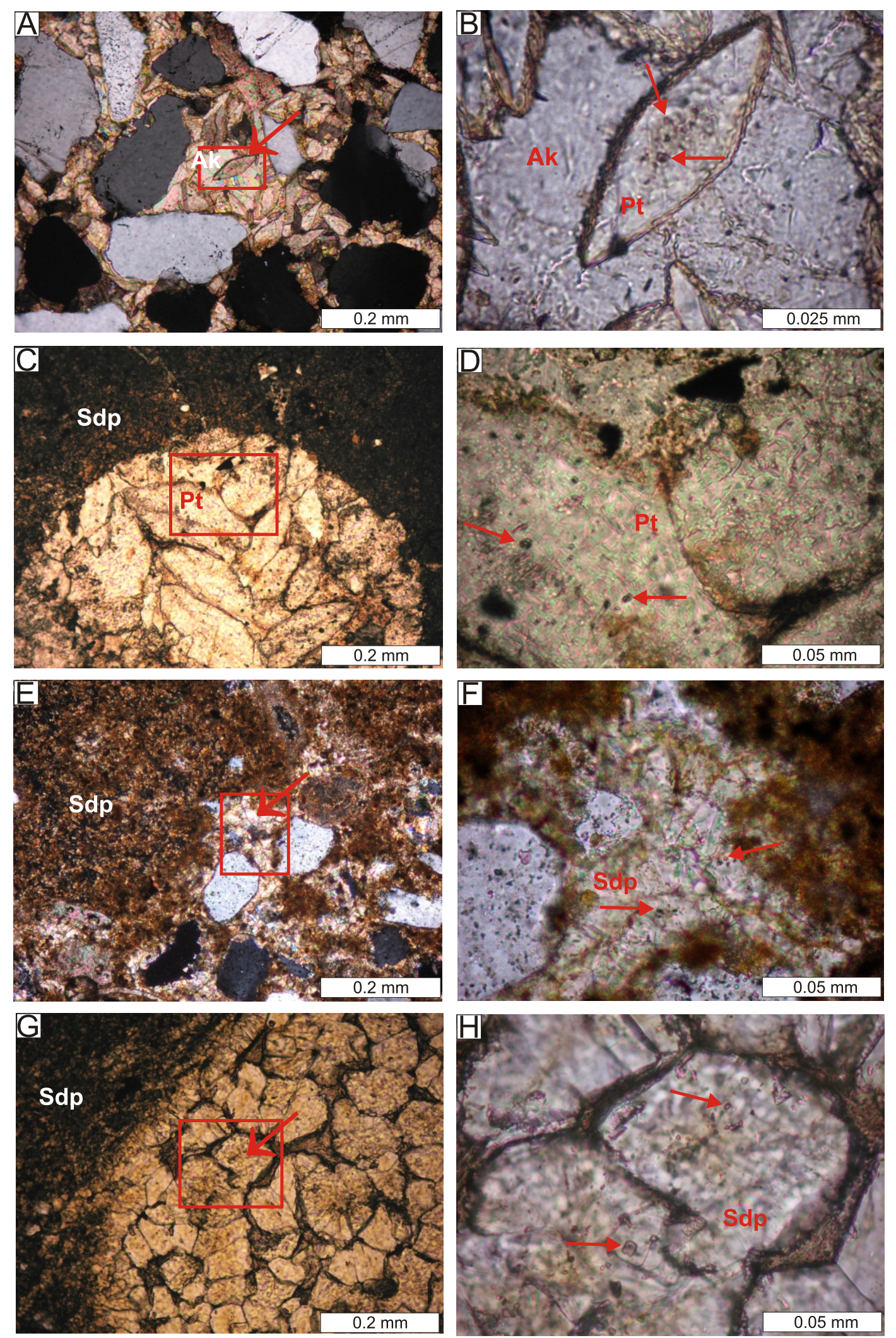

Fig. 3. Photographs in polarizing microscope (PL)

A - siderite represented by pistomesite rhombohedra (arrow) and ankerite cement (Ak) in sideritic sandstone (Gutwin borehole, depth $201.6 \mathrm{~m}$, crossed polars); B - part of photo A; two-phase inclusions (arrows) in pistomesite rhombohedron (Pt) and ankerite (Ak); plane polarized light; C - pistomesite ooids (Pt) in clayey siderite composed of sideroplesite micrite (Sdp); pistomesite in the form of rhombohedra (Waglany k/Opoczna borehole, depth $597.2 \mathrm{~m}$, plane polarized light); $\mathbf{D}$ - part of photo C; single two-phase inclusion (arrows) in pistomesite rhombohedron ( $\mathrm{Pt}$ ); plane polarized light; $\mathbf{E}$ - siderite cement: sparry sideroplesite (arrow) and micrite sideroplesite (Sdp) in sideritic sandstone (Biskupice 25BN borehole, depth $134.7 \mathrm{~m}$, crossed polars); $\mathbf{F}$ - part of photo E; one-phase inclusions (arrows) in sparry sideroplesite (Sdp); plane polarized light; G - sideroplesite ooid (arrow) and micrite sideroplesite (Sdp) in clayey siderite (Parkoszowice 58BN borehole, depth $101.2 \mathrm{~m}$, plane polarized light); $\mathbf{H}$ - part of photo G; two-phase inclusions (arrows) in sparry sideroplesite in ooid (Sdp); plane polarized light 

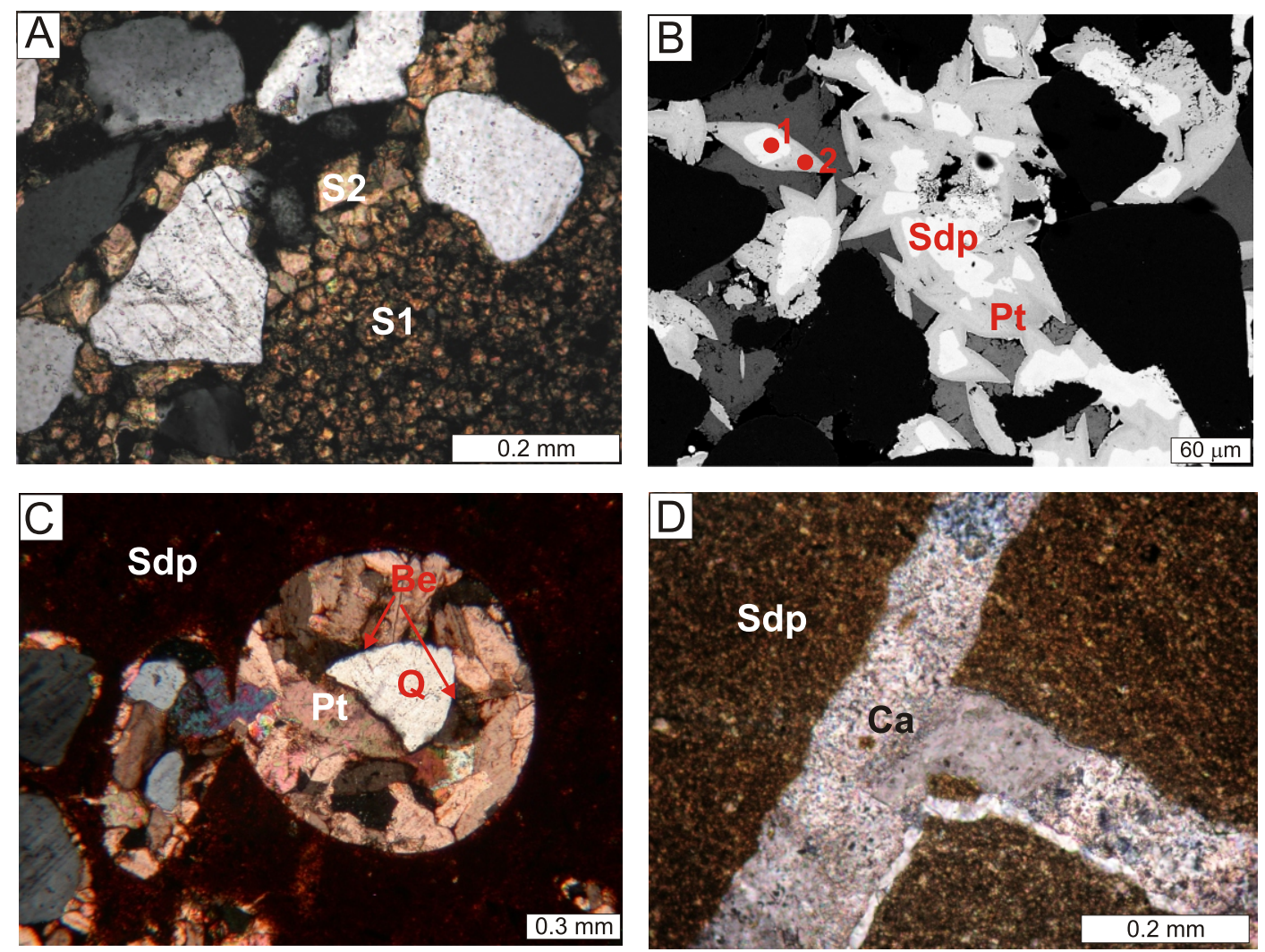

Fig. 4. Photographs by polarizing microscope (PL) and scanning electron microscope (BSE)

A - two generations of siderite - the early generation (S1 - microsparitic sideoplesite) and the late generation (S2 - sparitic sideoplesite) in clayey siderite (Łutowiec $135 Z$ borehole, depth178.9 m, crossed polars); B - zonal structure in rhombohedric crystals of sideroplesite (Sdp) and pistomesite (Pt) which form cement in siderite sandstone; 1, 2 - numbers of points of analysis (Appendix 1) (Gutwin borehole, depth 201.6 m, BSE image); C pistomesite $(\mathrm{Pt})$ ooids with berthierine $(\mathrm{Be})$ relicts in sideritic sandstone cemented by micritic sideroplesie (Sdp); quartz (Q) (Waglany k/Opoczna borehole, depth $597.2 \mathrm{~m}$, crossed polars); D - calcite (Ca) veins in clayey siderite with micritic sideroplesie (Sdp) (Parkoszowice 58BN borehole, depth $101.2 \mathrm{~m}$, crossed polars)

seen in BSE images (Fig. 4B). The siderite minerals can occur as a mass of clayey siderites, a cement filling the pore space in the sideritic sandstones (Fig. 4B) and a mineral replacing berthierine in ooids in the sideritic rocks (Fig. 4C). Some varieties of sideritic minerals contain fluid inclusions. This is why sparry individuals, often rhombohedra, of the sideroplesite and the pistomesite have been micro-thermometrically analysed (Fig. 3 and Appendix 2). The micritic siderite and sideroplesite, however, do not contain fluid inclusions. Inclusions in the microsparic crystals are too small to be measured. The calcite and ankerite either form cements in the sideritic rocks, or fill veins (Fig. 4D). These minerals also contain fluid inclusions. However, due to the low abundance and size of the inclusions, only some samples could have been selected for temperature measurements (Appendix 2). The isotopic analyses were conducted both in sideroplesite and pistomesite, as well as on calcite in the same samples (Table 2).

\section{GENERAL CHARACTERISTICS OF THE FLUID INCLUSIONS}

The liquid-vapour inclusions are small in size and not abundant. Their average size falls into the interval of $1-3 \mu \mathrm{m}$ that is difficult to observe in heating and freezing experimental modes. The inclusion shapes vary, but no form dominates. Some inclu- sions are oval, others are more or less regular in shape, or are shapeless. The rare occurrence and small sizes of inclusions are significant, occasional stretching symptoms may be noticed. The character of inclusions in general is primary. The inclusions are mostly one phase, locally with two phases. The fluid to vapour ratio varies, but generally the fluid volume prevails. Occasionally, the two-phase character of the inclusions corresponds to a co-presence of two liquid phases (L1 and L2). The fluid inclusions are randomly positioned, meaningful relations with crystallographic planes are hard to determine as is classification of distinct FIAs (Fluid Inclusion Association, sensu: Goldstein and Reynolds, 1994; Goldstein, 2003), which is not possible in practice due to the low abundance of two-phase fluid inclusions. In some cases, only one-phase inclusions were observed (e.g., in the Parkoszowice 58BN borehole).

\section{TEMPERATURE RESULTS OF FLUID INCLUSION STUDIES}

The carbonates in the sideritic rocks contain rare fluid inclusions. They exhibit a primary character, small size, and either one or two phases.

Temperature results are shown in Appendix 2. Microphotographs show inclusions in sideroplesite and pistomesite of selected rock samples (Fig. 3). As shown in the table, the following 
values have been measured for two-phase inclusions: temperature of homogenization $\left(T_{h}\right)$, ice melting temperatures $\left(T_{m}\right)$. For one-phase inclusions only $T_{m}$ values were determined, since no metastable contraction bubble was created during the experiment.

Temperature values are grouped in columns in Appendix 2, showing characteristic features such as eutectic temperature, ice melting, clathrate melting and homogenization values. The "Fluid" column gives a suggestion as to the possible type of the individual inclusion-fill, based on the individual temperature data. Fluid salinities and densities in the inclusions in simplified two-component systems are shown in Appendix 2.

Summing up the results, the number of measurements of homogenization temperatures $\left(T_{h}\right)$ in the sandstones is not large. The values of homogenization temperatures for the siderite fall into the interval between 60 and $100^{\circ} \mathrm{C}$. Temperatures of ice melting are relatively low and vary between -10.0 to $-3.4^{\circ} \mathrm{C}$. The salinity of fluids is moderately high and varies with respect to the type of cement and borehole location. The salinity corresponds to intervals from 7.8 to $13.9 \mathrm{wt} . \% \mathrm{NaCl}$ eq. and from 9.2 to $12.9 \mathrm{wt}$ \% $\mathrm{NaCl}$ eq. for siderite and calcite, respectively. The density of fluids is close to $1 \mathrm{~g} / \mathrm{cm}^{3}$. The eutectic temperatures are also variable and between -40 and $-30^{\circ} \mathrm{C}$. This suggests the presence of two valent cations in the brines, e.g., containing calcium and/or magnesium ions (Shephard et al., 1985; Schmidt Mumm and Wolfgramm, 2002).

\section{ISOTOPIC RESULTS}

Isotopic carbon and oxygen results are shown in Table 2 and in Figure 5, restricted to the samples studied by the fluid inclusion method. They are mostly for sideroplesite, with only some for pistomesite and calcite. Two siderite generations are often observed coexisting in the rocks, while only a few samples contain just one siderite generation (the early or the late one). Some isotopic results represent the cumulative products of varying proportions of two siderite generations (Table 2). The samples do not co-vary with the depth and age of the rocks.

At the northeastern margin of the Holy Cross Mts. the $\delta^{13} \mathrm{C}$ VPDB values in the early sideroplesite of the Aalenian age are $-8.63 \%$ and in the Batonian are $-17.68 \%$. The corresponding $\delta^{18} \mathrm{O}$ VPDB values are -7.84 and $-3.86 \%$. The $\delta^{13} \mathrm{C}$ VPDB values in the late sideroplesite and pistomesite of the Aalenian age are equal to -10.83 and $-9.58 \%$, respectively. The corresponding $\delta^{18} \mathrm{O}$ VPDB values are -8.82 and $-10.45 \%$.

In the Częstochowa region the $\delta^{13} \mathrm{C}$ VPDB values change in the Bajocian early sideroplesite from 22.85 to $-8.87 \%$ and the Batonian sideroplesite are $-7.48 \%$. The corresponding $\delta^{18} \mathrm{O}$ VPDB values are from -3.81 to $-1.92 \%$ and $-2.01 \%$. The $\delta^{13} \mathrm{C}$ VPDB value in the Batonian calcite is -2.01 and $\delta^{18} \mathrm{O}$ VPDB value is $-5.38 \%$.

\section{INTERPRETATION AND DISCUSSION}

\section{TEMPERATURE MEASUREMENTS}

The majority of carbonates occurring in the sideritic rocks show crypto- or fine crystalline crystal habits. This is why the inclusions were observed only in the sparry sideroplesite and pistomesite crystals and in the ankeritic and calcitic cement in the sideritic sandstones or clayey siderites.

Determination of inclusion character resulted in primary and secondary individuals. We have used Roedder's (1984) criterion: the primary inclusions are rare, randomly distributed and have no characteristic position in the cements of minerals. That makes the evaluation of inclusion character and genesis difficult. The size of inclusions of 1-3 $\mu \mathrm{m}$, type and lack of clarity of samples also causes difficulties in temperature measurements and observations in the freezing and heating modes. The processes were sometimes seen only partly during measurement cycles on the Linkam stage (Appendix 2).

Temperature results obtained for inclusions are those eutectic, homogenization and ice melting values (Appendix 2). However, not all characteristic temperature values were obtained for all the samples.

At the northeastern margin of the Holy Cross Mts., most measurements were performed on the cement-forming rhombohedric crystals of pistomesite and sideroplesite in sideritic rocks from the Waglany k/Opoczna borehole (Appendix 2). The homogenization temperatures there vary from 62 to $110^{\circ} \mathrm{C}$. In the rhombohedra of pistomesite cement in the sideritic sandstone from the Gutwin borehole homogenization temperatures lie in the interval between 107 and $139^{\circ} \mathrm{C}$. In the Waglany $\mathrm{k} / O$ poczna borehole the homogenization temperatures in the rhombohedric crystals of pistomesite in ooid were $\sim 137^{\circ} \mathrm{C}$ and the spar sideroplesite crystal in ooid showed $94.7^{\circ} \mathrm{C}$. Only one homogenization temperature value was obtained in ankerite cementing a sideritic coquina $\left(168^{\circ} \mathrm{C}\right)$. Other temperature values obtained in the Holy Cross Mts. area correspond to the eutectic temperatures that point to brine and carbon dioxide presence in the fluids in the inclusions. In some cases also clathrate and ice melting values were measured. Based on these data, it seems that in case of sideroplesite cement at a depth of $\sim 643 \mathrm{~m}$, the fluid is a brine of salinity between 10.5 and $12.9 \mathrm{wt} . \% \mathrm{NaCl}$ eq.

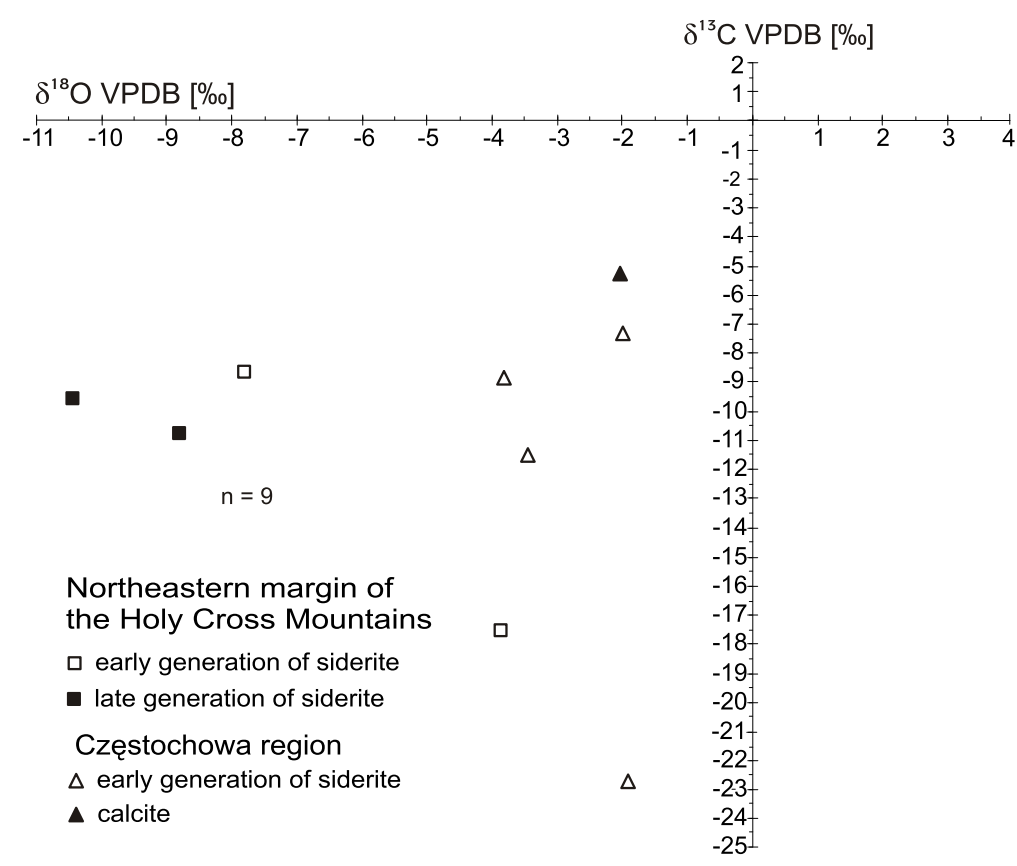

Fig. 5. Plot of the $\delta^{18} \mathrm{O}$ VPDB versus the $\delta^{13} \mathrm{C}$ VPDB in carbonate minerals 
and a density of $1.03-1.05 \mathrm{~g} / \mathrm{cm}^{3}$. The pistomesite cement from much shallower depth displays a very low fluid salinity in contrast to the ankeritic cement in the same borehole which reveals higher salinity and fluid density.

The following features can be described for the sideritic samples from the Częstochowa region in the minerals from the Parkoszowice 58BN borehole, which occur in a relative narrow depth interval: one-phase inclusion associations in sideroplesite, which point to trapping at temperatures of $40-50^{\circ} \mathrm{C}$ (Goldstein, 2001); variation of ice melting temperatures in the interval from -5.3 to $-9.7^{\circ} \mathrm{C}$. The $T_{m}$ results for the rhombohedric sideroplesite are between -5.3 and $-6.6^{\circ} \mathrm{C}$, while those for the sideroplesite in ooids are from -5.3 to $-9.7^{\circ} \mathrm{C}$, that corresponds to salinity intervals of between 7.8 and $10.5 \mathrm{wt} . \% \mathrm{NaCl}$ eq. and from 7.8 to $13.9 \mathrm{wt}$ \% $\mathrm{NaCl}$ eq., respectively. The ooids display a large scatter in values that may be connected with a variation of the fluid character during crystallisation of the inner/outer parts of the ooid. However, such a differentiation cannot be estimated because of the low abundance of fluid inclusions. Homogenization temperatures have been measured for individual inclusions. For calcite they mostly fall into the interval between 60 and $70^{\circ} \mathrm{C}$ (depth $104.1 \mathrm{~m}$ ). The salinity of fluids in calcite varies from 9.2 to 12.9 wt. \% $\mathrm{NaCl}$ eq.

The following characteristics may be presented for the sample from the Biskupice 25BN borehole (depth $134.7 \mathrm{~m}$ ): siderite character variability; one- and two-phase inclusion associations; variation of eutectic temperatures for brine inclusions from -52 to $-28^{\circ} \mathrm{C}$; variation of ice melting temperatures (from -3.4 to $-10.0^{\circ} \mathrm{C}$ ), whereas most of results for sideroplesite fall into the $T_{m}$ interval between -7.3 and $-10.0^{\circ} \mathrm{C}$ (in cements). Homogenization temperatures vary and fall into the interval between 55 and $100^{\circ} \mathrm{C}$ (sideroplesite). The salinity of fluids varies from 10.5 to 13.9 wt. $\% \mathrm{NaCl}$ eq.

In the sample from the Łutowiec $135 Z$ borehole (depth $178.9 \mathrm{~m}$ ) one-phase inclusions have been observed and a single ice melting value measured $\left(-4.4^{\circ} \mathrm{C}\right)$, that points to a low fluid salinity of about 6.37 wt.\% $\mathrm{NaCl}$ eq. and a density of $1.05 \mathrm{~g} / \mathrm{cm}^{3}$.

The following features have been recognized for the Zrębice 33BN borehole (depth $372.7 \mathrm{~m}$ ) in sideroplesite rhombohedra in cement: one-phase fluid inclusion associations; eutectic temperatures of $\sim-42^{\circ} \mathrm{C}$ (more complex system than the two-component brine); variation in ice melting temperatures (from -6.2 to $-9.2^{\circ} \mathrm{C}$ ), that implies salinity in the interval from 9.2 to 12.9 wt. $\% \mathrm{NaCl}$ eq. and fluid density of $1.07 \mathrm{~g} / \mathrm{cm}^{3}$; potential presence of carbon dioxide in two-phase aqueous inclusions. That last feature is similar to the observations reported by Hurai et al. (2002) for siderites in the Carpathian veins.

Observations of fluid inclusions together with varying homogenization temperatures of two-phase inclusions, their variable $L: V$ ratio, suggest that the temperature data obtained for them have a random character not constraining the primary conditions of cement formation.

The ice melting temperature results after freezing are very significant and valuable for interpretation. Based on these values obtained in fluid inclusion studies, a complex character of fluids in individual samples may be deduced. The most simple way to present these results is to express them as a wt. $\% \mathrm{NaCl}$ eq. Using standard calculation programs for $\mathrm{H}_{2} \mathrm{O}-\mathrm{NaCl}$ system (FLUIDS package, AqSo1e program) fluid salinities and density have been obtained, in the interval from 8.2 to 14.0 mass $\%$ $\mathrm{NaCl}$ and of about $1 \mathrm{~g} / \mathrm{cm}^{3}$, respectively.

The relationship between the homogenization temperatures and fluid salinity for the two-phase inclusions is shown in Figure 6.

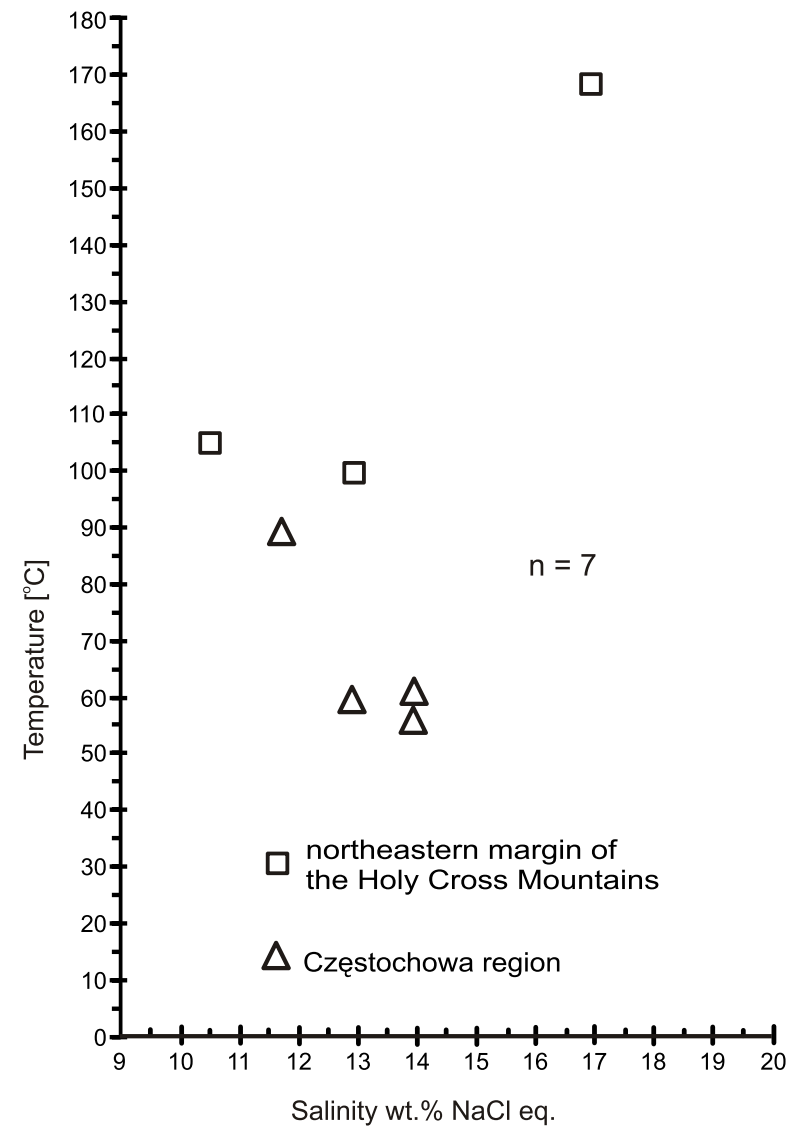

Fig. 6. Homogenization temperature versus fluid salinity in two-phase inclusions

$\mathrm{n}-$ number of analyses

The eutectic temperatures close to $-30^{\circ} \mathrm{C}$ or even $-40^{\circ} \mathrm{C}$ suggest (especially in calcite) a presence of more complex fluids than the simple system of $\mathrm{NaCl}-\mathrm{H}_{2} \mathrm{O}$, as for example $\mathrm{H}_{2} \mathrm{O}-\mathrm{NaCl}-\mathrm{CaCl}_{2}-\mathrm{MgCl}_{2}$ (Shephard et al., 1985; Bodnar, 2003). Based on the AqSo1e (system $\mathrm{H}_{2} \mathrm{O}-\mathrm{NaCl}-\mathrm{CaCl}_{2}$ ) and AqSo3e (system $\mathrm{H}_{2} \mathrm{O}-\mathrm{NaCl}-\mathrm{MgCl}_{2}$ ) programs such a trial of calculations for multi-component systems has been made, though with several assumptions introduced. Due to this fact (e.g., lack of exact mole ratios), the results obtained after the Oakes et al. equation (1990, fide: Bakker and Brown, 2003) should be regarded as approximate.

\section{ISOTOPES}

The carbon and oxygen isotopic results in both regions studied are similar. Most determinations concern the samples where the early siderite predominates over the late one (Table 2). Two-isotope data have been obtained in the samples containing a late generation of siderite from the same depths as those studied for fluid inclusions.

The results of $\delta^{13} \mathrm{C}$ determinations for early generation of siderite-sideroplesite fall within the range of -22.85 to $-7.48 \%$ o VPDB. They indicate that the sideroplesite was formed in the zone of microbiological methanogenesis, where a bacterial fermentation of the organic components was the $\mathrm{CO}_{2}$ source (Irvin et al., 1977; Morad, 1998). The $\delta^{18} \mathrm{O}$ values range between -7.84 and $-1.92 \%$ VPDB. The formula after Carothers et al. (1988) has been used to estimate the $\delta^{18} \mathrm{O}$ of the pore water responsible for 
crystallisation of the early siderite generation. The $\delta^{18} \mathrm{O}$ values suggest that the early sideroplesite precipitated from water of $\delta^{18} \mathrm{O}$ VSMOW in the range of -11.11 to $-5.01 \%$, assuming a crystallisation temperature of about $20^{\circ} \mathrm{C}$ (Baker et al., 1995; Rezaee and Schulz-Rojahn, 1998). Such values indicate a mixture of marine and meteoric waters.

The results of $\delta^{13} \mathrm{C}$ and $\delta^{18} \mathrm{O}$ determinations for the late generation of siderite were obtained only for the rocks from the northeastern margin of the Holy Cross Mts. The results of $\delta^{13} \mathrm{C}$ determinations for late generation of siderite - sideroplesite and pistomesite are -10.83 and $-9.58 \%$ VPDB. The late generation of siderite is characterized by a high magnesium content. According to Macaulay et al. (1992), altered minerals rich in $\mathrm{Mg}^{+2}$, e.g. micas, could have been a magnesium source. According to Desborough (1978) the magnesium could have been released from kerogen during sediment burial. It seems that in the rocks under study, carbon released from organic matter in the thermal decarboxylation zone might have been a source of this element for the late, Mg-rich siderite generation. The same source of carbon for Mg-rich siderites was suggested by Morad et al. (1994) and Rezaee and Schulz-Rojahn (1998). The $\delta^{18} \mathrm{O}$ values are -8.82 and $-10.45 \%$ VPDB. The homogenization temperatures for the late siderite generation were $90-110^{\circ} \mathrm{C}$ and $62-98.8^{\circ} \mathrm{C}$, respectively (Appendix 2 ). The temperature data calculated with use of the Carothers et al. (1988) formula point to precipitation of the late siderite from the pore waters displaying $\delta^{18} \mathrm{O}$ in the interval from about -5 to $3.5 \%$ SMOW, most often $>0 \%$ SMOW (Fig. 7). Such values of $\delta^{18} \mathrm{O}$ for pore water suggested that the late siderite has precipitated from waters richer in the ${ }^{18} \mathrm{O}$ isotope in comparison with the water composition of the early siderite crystallisation. The enrichment in the oxygen isotope content in pore waters is already possible at several hundred metres of burial due to the water-sediment interaction (McKay et al., 1995).

The oxygen and carbon isotopic values in the calcite cement were obtained for one sample from the Czestochowa region. The $\delta^{13} \mathrm{C}$ value points to organic matter as the carbon source (Baker,

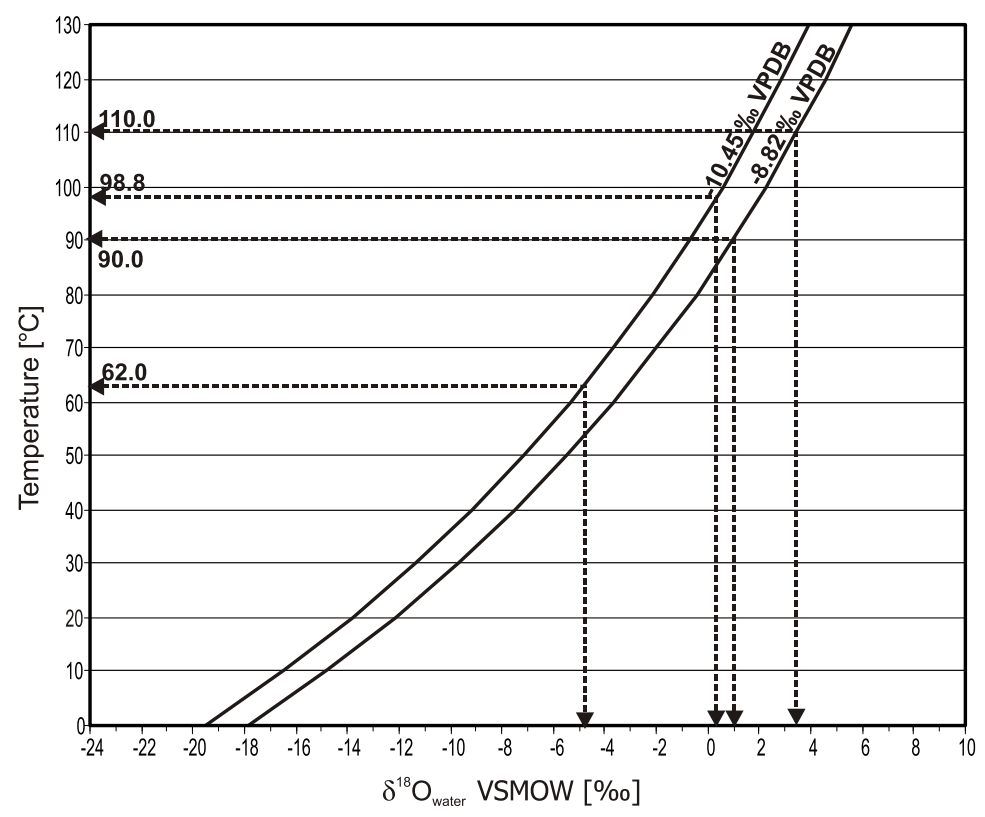

Fig. 7. Plot of $\delta^{18} \mathrm{O}$ pore water versus temperature for the late generation of siderite (Carothers et al., 1988)
1991). It was impossible to measure a homogenization temperature in this sample. Measurements were performed in the calcitic vein on another sideritic rock. The values of 59.8 and $67.8^{\circ} \mathrm{C}$ (Appendix 2) have been regarded as a probable temperature of calcite crystallisation. The isotopic and temperature values for calcite have been used in the Friedman and O'Neil (1977) formula. For the calcite crystallisation, they point to the $\delta^{18} \mathrm{O}$ pore water equal to about $0 \%$ VSMOW.

\section{CONCLUSIONS}

1. The main carbonate minerals of the Middle Jurassic sideritic rocks at the northeastern margin of the Holy Cross Mts. and in the Częstochowa region are represented by sideroplesite, less frequent pistomesite, and siderite. They form cements and ooids. Early and late generations of siderite have been distinguished. Apart from this mineral, calcite and ankerite in the form of cements and veinlets are present as well.

2. One-phase inclusions and associations of two-phase inclusions with a different phase ratio are predominant. As compared with the Czestochowa region, two-phase inclusions are more abundant and the phase ratios are more homogeneous at the northeastern margin of the Holy Cross Mts.

3. The salinity of fluids in the inclusions varies in the range between 1.7 and $16.9 \mathrm{wt} \% \mathrm{NaCl}$ eq. for siderites in the rocks from the northern margin of the Holy Cross Mts. The fluid density is close to $1 \mathrm{~g} / \mathrm{cm}^{3}$ in the Częstochowa region, and the salinity oscillates between 6.4 and $13.9 \mathrm{wt} \% \mathrm{NaCl}$ eq. It varies for siderites in form of the cements and those occurring as ooids. The fluid density is also close to $1 \mathrm{~g} / \mathrm{cm}^{3}$. Complex chemical brine systems may occur as fluids, e.g., $\mathrm{H}_{2} \mathrm{O}-\mathrm{NaCl}-\mathrm{CaCl}_{2}-$ $\mathrm{MgCl}_{2}$ or $\mathrm{H}_{2} \mathrm{O}-\mathrm{CaCl}_{2}-\mathrm{MgCl}_{2}$ as well as mixed ones $\left(\mathrm{H}_{2} \mathrm{O}-\mathrm{CO}_{2}\right)$.

4. Studies of two-phase fluid inclusions present in the crystals of the late siderite generation - sideroplesite and pistomesite - in the Middle Jurassic sideritic sandstones and clayey siderites, display homogenization temperatures in the interval of $55.0-137.1^{\circ} \mathrm{C}$. They suggest crystallisation in deep burial conditions. The calcite in the veinlet showed a temperature of $\sim 60^{\circ} \mathrm{C}$. Higher homogenization temperatures of $\sim 168^{\circ} \mathrm{C}$ were determined in the ankeritic cement of a siderite coquina.

5. The temperature results vary with respect to the borehole and the type of cement in both regions. The character of inclusions and the homogenization temperature results are very different. The rocks occur at the depth of about 100 to $>600 \mathrm{~m}$, and no temperature tendency may be observed, either as regards depth or type of cement.

6 . The homogenization temperatures in the carbonates, are slightly higher than the results obtained in the Middle Jurassic sandstones in sideritic rocks in the Polish Lowlands (Maliszewska et al., 2007). These facts support the authors' conclusion that, apart from burial, another heat source was a cause of increased temperatures characteristic for the lithogenesis of the Jurassic deposits.

7. The isotopic determinations of $\delta^{13} \mathrm{C}$ VPDB (from -22.85 to $-7.48 \%$ VPDB) in the early siderite generation point to formation of this mineral in the zone of microbiological methanogenesis. The isotopic oxygen composition $\delta^{18} \mathrm{O}$ VPDB (from -7.84 to $-1.92 \%$ o VPDB) points to siderite precipitation from marine and also meteoric waters at temperatures of $\sim 20^{\circ} \mathrm{C}$. 
8. The results of $\delta^{13} \mathrm{C}$ for the late generation of siderite ( -10.83 and $-9.58 \%$ VPDB) suggest that carbon could have been released from the organic matter in the thermal decarboxylation zone. Based on data compilation of $\delta^{18} \mathrm{O}$ values (-8.82 and $-10.45 \%$ VPDB) and of homogenization temperatures $\left(90-110^{\circ} \mathrm{C}\right.$ and $\left.62-98.8^{\circ} \mathrm{C}\right)$ the conclusion can be drawn that the late siderite generation crystallized from pore waters of $\delta^{18} \mathrm{O}>0 \%$ o VSMOW. The calcite also precipitated from the pore waters with $\delta^{18} \mathrm{O}$ of about $0 \%$ VSMOW.

9. Values of $\delta^{18} \mathrm{O}$ VSMOW of pore water for the late siderite and calcite generations are higher when compared with those characteristic for the water responsible for the early siderite crystallisation. An enrichment in ${ }^{18} \mathrm{O}$ isotope might have been caused either by a water-rock reaction during burial of the deposit or by an influx of the marine water to the sediment.

Acknowledgements. The authors are very grateful to the reviewers of the manuscript - L.A. Palinkaš and Z. Sawłowicz, whose critical comments and corrections improved the content of the paper. Cordial thanks are addressed to T.M. Peryt for his constant help and favour. The present paper is a part of the project No. N N307 330339 financed by the Ministry of Science and High Education, and no. 61.2201.0604.00.0 of the Polish Geological Institute - National Research Institute.

\section{REFERENCES}

Al-Aasm, I.S., Taylor, B.E., South, B., 1990. Stable isotope analysis of multiple carbonate samples using selective acid extraction. Chemical Geology, 80: 119-125.

Baker, J.C., 1991. Diagenesis and reservoir quality of the Aldebaran Sandstone, Denison Trough, east-central Queensland, Australia. Sedimentology, 38: 819-838.

Baker, J.C., Kassan, J., Hamilton, P.J., 1995. Early diagenetic sid erite as indicator of depositional environment in the Triassic Rewan Group, Southern Bowen basin, eastern Australia. Sedimentology, 43: 77-88.

Bakker, R.J., 2003. Package FLUIDS 1. Computer programs for analysis of fluid inclusion data and for modeling bulk fluid properties. Chemical Geology, 194: 3-23.

Bakker, R.J., Brown, P.E., 2003. Computer modeling in fluid inclusion research. Mineralogical Association of Canada Short Course, 32: 175-203.

Bodnar, R.J., 2003. Interpretation of data from aqueous-electrolyte fluid inclusions. Mineralogical Association of Canada Short Course, 32: 81-101.

Bolewski, A., 1982. Mineralogia szczegółowa (in Polish). Wyd. Geol., Warszawa.

Brown, P.E., 1989. FLINCOR: a microcomputer program for the reduction and investigation of fluid inclusion data. American Mineralogist, 74: 1390-1393.

Carothers, W.W., Adami, L.H., Rosenbauer, R.J., 1988. Experimental oxygen isotope fractionation between siderite-water and phosphoric acid liberated $\mathrm{CO}_{2}$ - siderite. Geochimica et Cosmochimica Acta, 52: 2445-2450.

Daniec, J., 1970. Middle Jurassic (in Polish with English summary). Prace Instytutu Geologicznego, 56: 99-134.

Desborough, G.A., 1978. A biogenic-chemical stratified lake model for the origin of oil shale of the Green River Formation: on alternative to the playa-lake model. GSA Bulletin, 89: 961-971.

Durakiewicz, T., 1996. Electron emission controller with pulsed heating of filament. International Journal Mass Spectrometry Ion Processes, 156: 31-40.

Durakiewicz, T., Hałas, S., 1994. Triple collector system for isotope ratio mass spectrometer. IF UMCS Scientific Report 1994: 131-132.

Feldman-Olszewska, A., 1998. Palaeogeographical maps of Middle Jurassic, pl. 36-47. In: Palaeogeographical atlas of the epicontinental Permian and Mesozoic in Poland (eds. R. Dadlez, S. Marek and J. Pokorski). Państwowy Instytut Geologiczny, Warszawa.

Fernández-Nieto, C., Torres-Ruiz, J., Subías Pérez, I., Fanlo González, I., Gonzáles López, J.M., 2003. Genesis of Mg-Fe carbonates from the Sierra Menera magnesite-siderite deposits, northeast Spain: evidence from fluid inclusions, trace elements, rare earth elements, and stable isotope data. Economic Geology, 98: 1413-1426.
Friedman, I., O'Neil, J., 1977. Compilation of stable isotope fractionation factors of geochemical interest. U.S. Geological Survey, Professional Paper, 440-K: 1-12.

GedI, P., Ziaja, J., 2012. Palynofacies from Bathonian (Middle Jurassic) ore-bearing clays at Gnaszyn, Kraków-Silesian Homocline, Poland, with special emphasis on sporomorph ecogroups. Acta Geologica Polonica, 62: 325-349.

Goldstein, R.H., 1986. Re-equilibration of fluid inclusions in low temperature calcium-carbonate cements. Geology, 14: 792-795.

Goldstein, R.H., 2001. Fluid inclusions in sedimentary and diagenetic systems. Lithos, 55: 159-193.

Goldstein, R.H., 2003. Petrographic analysis of fluid inclusions. Mineralogical Association of Canada, Short Course, 32: 9-54.

Goldstein, R.H., Reynolds, T.J., 1994. Systematics of fluid inclusions in diagenetic minerals. SEPM Short Course, 31.

Hein, U.F., 1993. Synmetamorphic Variscan siderite mineralisation of the Rhenish Massif, Central Europe. Mineralogical Magazine, 57: 451-467.

Hurai, V., Harčová, E., Huraiová, M., Ozdín, D., Prochaska, W., Wiegerová, V., 2002. Origin of siderite veins in the Western Carpathians, I. P-T-X- $\delta{ }^{18} \mathrm{O}$ relations in ore-forming brines of the Rudňany deposits. Ore Geology, 21: 67-101.

Irvin, H., Curtis, C., Coleman, M., 1977. Isotopic evidence for source of diagenetic carbonates formed during burial of organic-rich sediments. Nature, 269: 209-213.

Jarmołowicz-Szulc, K., 1999. Fluid inclusion systematics in the filling of the pore space of Paleozoic sedimentary rocks in the Polish Lowlands (in Polish with English summary). Przegląd Geologiczny, 47: 542-546.

Jarmołowicz-Szulc, K., 2001. Fluid inclusion studies in quartz cements in the Middle Cambrian sandstones in the Łeba Block in the Baltic Sea - diagenetic, isotope and geochemical implications (in Polish with English summary). Biuletyn Państwowego Instytutu Geologicznego, 399: 1-74.

Jarmołowicz-Szulc, K., 2015. Fluid inclusion analysis of minerals in sedimentary rocks in Poland - an overview and remarks (in Polish with English summary). Biuletyn Państwowego Instytutu Geologicznego, 464: 25-42.

Kopik, J., 1998. Lower and Middle Jurassic of the north-eastern margin of the Upper Silesian Coal Basin (in Polish with English summary). Prace Państwowego Instytutu Geologicznego, 378: 67-131.

Kozłowska, A., 1997. Carbonate cements of the Carboniferous sandstones in NW part of the Lublin Graben (eastern Poland) (in Polish with English summary). Przeglad Geologiczny, 45: 301-304.

Kozłowska, A., 2001. Syderyty magnezowe w piaskowcach górnokarbońskich środkowej Polski (in Polish). Przegląd Geologiczny, 49: 343-344.

Kozłowska, A., 2004. Diagensis of the Upper Carboniferous sandstones occurring at the border of the Lublin Trough and the War- 
saw Block (in Polish with English summary). Biuletyn Państwowego Instytutu Geologicznego, 411: 5-86.

Kozłowska, A., Maliszewska, A., 2015. Berthierine in the Middle Jurassic sideritic rocks from southern Poland. Geological Quarterly, 59 (3): 551-564.

Krzykawski, T., 2012. Mineralogy of the Middle Jurassic siderite concretions from the selected exposures in the Silesian-Cracow Monocline (in Polish with English summary). Ph.D. thesis, Silesian University, Katowice.

Leonowicz, P., 2012. Sedimentology and ichnology of Bathonian (Middle Jurassic) ore-bearing clays at Gnaszyn, Kraków-Silesian Homocline, Poland. Acta Geologica Polonica, 62: 281-296.

Leonowicz, P., 2013. Significance of mudstone fabric combined with palaeoecological evidence in determining sedimentary processes - an example from the Middle Jurassic of Southern Poland. Geological Quarterly, 57 (2): 243-260.

Leonowicz, P., 2015. Storm-influenced deposition and cyclicity in a shallow-marine mudstone succession - example from the Middle Jurassic ore-bearing clays of the Polish Jura (southern Poland). Geological Quarterly, 59 (2): 325-344.

Lott, G., Wong, T., Dusar, M., Andsbjerg, J., Monnig, E., Feldman-Olszewska, A., Verreussel, R., 2010. Jurassic. In Petroleum Geological Atlas of the Southern Permian Basin Area (eds. H. Doornenbal and A. Stevenson): 173-193. EAGE Publications, Houten.

Lugli, S., Morteani, G., Blamart, D., 2002. Petrographic, REE, fluid inclusion and stable isotope study of magnesite from the Upper Triassic Burano Evaporites (Secchia Valley, northern Apennines): contributions from sedimentary, hydrothermal and metasomatic sources. Mineralium Deposita, 37: 480-494.

Macaulay, C.I., Haszeldine, R.S., Fallick, A.E., 1992. Distribution, chemistry, isotopic composition and origin of diagenetic carbonates: Magnus Sandstones, North Sea. Journal of Sedimentary Petrology, 63: 33-43.

Majewski, W., 2000. Middle Jurassic concretions from the Częstochowa (Poland) as indicators of sedimentation rates. Acta Geologica Polonica, 50: 431-439.

Maliszewska, A., Kozłowska, A., Kuberska, M., 2007. Diagenesis of the Middle Jurassic sideritic rocks from Central and NW Poland (in Polish). Przegląd Geologiczny, 55: 297-298.

Marynowski, L., Zatoń, M., Simoneit, B.R.T., Otto, A., Jędrysek, M.O., Grelowski, C., Kurkiewicz, S., 2007. Compositions, sources and depositional environments of organic matter from the Middle Jurassic clays of Poland. Applied Geochemistry, 22 2456-2485.

McCrea, J.M., 1950. On the isotopic geochemistry of carbonates and a paleotemperature scale. Journal of Chemical Physics, 18: 849-857.

McKay, J.L., Longstafee, F.J., Plint, A.G., 1995. Early diagenesis and its relationship to depositional environment and relative sea-level fluctuations (Upper Cretaceous) Marshybank Formation, Alberta and British Columbia. Sedimentology, 42: 161-190.
Morad, S., 1998. Carbonate cementation in sandstones: distribution patterns and geochemical evolution. IAS Special Publication, 26: 1-26.

Morad, S., Ben Ismail, H.N., De Ros, L.F., Al-Aasm, I.S., Sherrhini, N.E., 1994. Diagenesis and formation water chemistry of Triassic reservoir sandstones from Southern Tunisia. Sedimentology, 41: 1253-1272.

Palinkaš, L.A., Borojević Šoštarić, S., Strmić Palinkaš, S. Prochaska, W., Pécskay, Z., Neubauer, F., Spangenberg, J., 2016. A Ljubija geothermal field: a herald of the Pangea break-up (NW Bosnia and Herzegovina). Geologia Croatica, 69: 3-30.

Pieńkowski, G., Schudack, M.E. (co-ordinators), Bosák, P., Enay, R., Feldman-Olszewska, A., Golonka, J., Gutowski, J., Herngreen, G.F.W., Jordan, P., Krobicki, M., Lathuiliere, B., Leinfelder, R.R., Michalík, J., Mönnig, E., Noe-Nygaard, N., Pálfy, J., Pint, A., Rasser, M.W., Reisdorf, A.G., Schmid, D.U., Schweigert, G., Surlyk, F., Wetzel, A., Wong, T.E., 2008. Jurassic. In: The Geology of Central Europe (ed. T. McCann): 823-922, 2 (Mesozoic and Cenozoic). Geological Society of London.

Rezaee, M.R., Schulz-Rojahn, J.P., 1998. Application of quantitative back-scattered electron image analysis in isotope interpretation of siderite cement: Tirrawarra sandstone, Cooper Basin, Australia. IAS Special Publication, 26: 461-481.

Roedder, E., 1984. Fluid inclusions. Reviews in Mineralogy, 12 $1-254$.

Schmidt Mumm, A.S., Wolfgamm, M., 2002. Diagenesis and fluid mobilisation during the evolution of the North German basin evidence from fluid inclusion and sulphur isotope analysis. Marine and Petroleum Geology, 19: 229-246.

Shephard, T.J., Rankin, A.H., Alderton, D.H.M., 1985. A Practical Guide to Fluid Inclusion Studies. Blackie, New York.

Strmić Palinkaš, S., Spangenbeg, J.E., Palinkaš, L.A., 2009. Organic and inorganic geochemistry of Ljubija siderite deposits, NW Bosnia and Herzegovina. Mineralium Deposita, 44: 893-913.

Szczepanik, P., Witkowska, M., Sawłowicz, Z., 2007. Geochemistry of Middle Jurassic mudstones (Kraków-Częstochowa area, southern Poland): interpretation of the depositional redox conditions. Geological Quarterly, 51 (1): 57-66.

Wierzbowski, H., Joachimski, M., 2007. Reconstruction of late Bajocian-Bathonian marine palaeoenvironments using carbon and oxygen isotope ratios of calcareous fossils from the Polish Jura Chain (central Poland). Palaeogeography, Palaeoclimatology, Palaeoecology, 254: 523-540.

Witkowska, M., 2012. Palaeoenvironmental significance of iron carbonate concretions from the Bathonian (Middle Jurassic) ore-bearing clays at Gnaszyn, Kraków-Silesian Monocline, Poland. Acta Geologica Polonica, 62: 307-324.

Witkowska, M., 2015. Mineralogia i geochemia konkrecji węglanowych w iłach jury środkowej na monoklinie śląsko-krakowskiej (in Polish). Ph.D. thesis, Jagiellonian University, Kraków.

Zatoń, M., Marynowski, L., Szczepanik, P., Bond, D.P.G., Wignall, P.B., 2009. Redox conditions during sedimentation of the Middle Jurassic (Upper Bajocian-Bathonian) clays of the Polish Jura (south-central Poland). Facies, 55: 103-114. 